\title{
Adult GH deficiency throughout lifetime
}

\author{
Julia D J Thomas and John P Monson \\ Department of Endocrinology, St Bartholomew's Hospital, Barts and the London School of Medicine and Dentistry, \\ Queen Mary University of London, London EC1M 6BQ, UK \\ (Correspondence should be addressed to J P Monson; Email: johnmonson@aol.com)
}

\begin{abstract}
It is now accepted that adults with severe GH deficiency (GHD) demonstrate impaired physical and psychological well-being and may benefit from replacement with recombinant human GH. Postmarketing surveillance surveys, such as the Pfizer International Metabolic Database (KIMS), were initially set-up to provide safety data on long-term treatment but have the added benefit of providing ongoing observational data on the effect of GH replacement on body composition, lipid and glucose status, hypertension, bone density and quality of life. These data demonstrate that although GHD has clinical impact at all ages, the individual consequences of this condition may take on greater significance at different stages in life. At all ages, accurate, safe diagnosis and appropriate GH dosing are necessary to provide the individual with the best possible outcome.
\end{abstract}

European Journal of Endocrinology 161 S97-S106

\section{Introduction}

Therapeutic patient databases, such as the Pfizer International Metabolic Database (KIMS), have formed the basis of much of our understanding regarding the optimum use of GH replacement. The conclusions that can be drawn from such resources will always be limited by their open, non-randomised nature, with the risk of enrolment bias, missing data and lack of valid comparisons (1). However, taken in combination with controlled studies, they provide a wealth of supportive data. Furthermore, the large numbers of patients enrolled permit subgroup analysis that would not be feasible on a local level. This has allowed for the characterisation of GH deficiency (GHD) in different phases of adult life and for the assessment of the effect of GH replacement across the entire adult age range (2). Such databases allow for the documentation of adverse events and safety monitoring, a prerequisite at all stages of life.

The impact of the individual consequences of adult GHD may vary at different stages of life. In the young adult who has completed linear growth, $\mathrm{GH}$ has a continuing and important role in achievement of maximum bone density and lean body mass (LBM). In middle age, the year on year negative impact of GHD on cardiovascular risk factors becomes of increasing importance. In older patients, the effect of GHD

This paper forms part of a special issue on $\mathrm{KIMS}^{\circledR}$ and ACROSTUDY $^{\mathrm{TM}}$. Pfizer Inc. has supported the publication of this special issue. on body composition may become less relevant as other age-related physiological changes predominate. It could be argued that quality of life (QoL) issues are the major consideration in the older patient but we should remain aware of GHD-related cardiovascular and bone morbidity in this age group. Furthermore, there is much evidence to indicate that GHD-related QoL deficit is very important in younger adults, although this may be difficult to quantify in adolescents.

Hypopituitarism and GHD are associated with increased mortality, with several studies showing an increased standardised mortality ratio (SMR) in hypopituitary patients who are receiving conventional hormone therapy (glucocorticoid, thyroxine and sex steroids) excluding $\mathrm{GH}$ (3-5). Although the most recent of these studies failed to demonstrate GHD as an independent risk factor for increased SMR, it should be borne in mind that the substantial majority of patients surveyed in this study had not undergone a dynamic test of pituitary function. These patients were not designated as having GHD in regression analysis, although it is highly likely that they were indeed GHD as evidenced by their additional pituitary hormone deficiencies and therefore the study could not specifically refute an aetiological role for GHD in increasing mortality rate (4). Open studies of $\mathrm{GH}$ replacement have been associated with normalisation of mortality rates. Svensson et al., in an open prospective study, found that after 3 years GH replacement mortality rates were no different to background population rates and were improved compared with mortality rates in a historical hypopituitary cohort not treated with GH 
(6). Both the increased mortality in hypopituitary patients and the possible improvement in mortality seen with GH replacement are likely to arise from a host of hormonal and non-hormonal interactions, the complexity of which hinders easy interpretation. Furthermore, recent medical interventions distinct from GH replacement, including improved control of cardiovascular risk factors, may play a major role in improving SMR when contrasted with historical control data. Similarly, although data from KIMS indicate normal SMR in patients on long-term GH replacement, the impact of bias in patient selection for $\mathrm{GH}$ replacement and the favourable effects of enhanced clinical care render it difficult to define a precise beneficial effect of $\mathrm{GH}$ on mortality at the present time.

In this review, we will examine the clinical features of GHD and the response of these to GH replacement with particular reference to the impact of age.

\section{Diagnosis}

The gold standard for confirming GHD in the hypopituitary patient is the insulin tolerance test (ITT). This was the first test validated in patients with structural pituitary lesions (7) and has been demonstrated to be safe when performed in an experienced endocrine unit (8). It should be interpreted with caution in the significantly obese as false positives may occur (9). International consensus guidelines suggest that only adults with severe GHD, as defined by a peak $\mathrm{GH}<3 \mu \mathrm{g} / \mathrm{l}$ on ITT, should receive $\mathrm{GH}$ replacement (10). This contrasts with the paediatric population in which GH therapy may be given in the presence of normal GH reserve for the treatment of short stature, and moderate GHD is treated in order to enhance linear growth. In children treated for GHD, therapy should be continued beyond the achievement of target height, usually between 17 and 19 years, until full somatic development is reached in the mid to late 20s; this period of time reflects the transition between adolescence and full adult development. Guidelines have been issued by the European Society of Paediatric Endocrinology regarding the investigation and management of GHD during this period (11). There is some evidence that even in the absence of severe deficiency, partial GHD in young people (peak GH response 3-11.8 $\mu \mathrm{g} / \mathrm{l}$ on provocation testing) may have a negative effect on body habitus (12). This raises the possibility of future increased morbidity and mortality in these patients, although strategies for their future surveillance remain poorly defined.

In older patients, hypoglycaemia also acts as a potent GH secretagogue; Kalk et al. found no difference in $\mathrm{GH}$ response to ITT in a group of healthy elderly people (mean age 76 years) when compared with younger controls (mean age 32.7 years) (13), although some studies are at variance with this finding (14). As the likelihood of cardiovascular or seizure-related contraindications to ITT increases with age, alternative tests of $\mathrm{GH}$ reserve may be required. Glucagon may be considered an acceptable alternative, whereas isolated arginine is limited by marked variation in response according to body mass index (BMI) (15) and clonidine, although useful in children, is a poor test in adults $(16,17)$. $\mathrm{GH}-$ releasing hormone (GHRH) in isolation is not an appropriate test of the hypothalamic-pituitary unit and is limited by the problems of all hypothalamic releasing-hormone tests in the assessment of overall hypothalamic-pituitary function. However, the combination of GHRH with arginine or GH secretagogues (such as GHRP-6) demonstrates considerable utility in separating hypopituitary patients from controls (15, 18). In a study of GHRH with GHRP-6, no difference in $\mathrm{GH}$ response was seen between young adults $(22 \pm 1.1$ years) and older patients $(59.5 \pm 1.7$ years) (19), suggesting its suitability in the older patient in whom the ITT may be contraindicated. It should be noted that when using GHRH in combination with arginine, BMIspecific diagnostic cut-offs exist to reflect the blunted GH response this test achieves in obese individuals (15). The increased availability of GHRH combination tests has resulted in changes in diagnostic practices: the hypopituitary control and complications study (HypoCCS), an observational database, demonstrated a shift in clinical practice away from isolated arginine, clonidine and L-dopa testing towards an increased use of the GHRH-arginine test between 1996 and 2005 (20). Whichever test is used, test and laboratory-specific diagnostic cut-offs need to be determined to allow for accurate diagnosis and management.

The sensitivity of serum insulin-like growth factor-1 (IGF1) as a marker of GHD declines with age, despite age-specific IGF1 reference ranges. It has been reported that virtually all young men (mean age 26.5 years) with GHD have a serum IGF1 level below the lower limit of the age-adjusted reference range (21). The consistency of this finding is augmented by the lower IGF1 concentrations found in childhood-onset GHD. However, this reliability declines with age and Toogood et al. found that only $21 \%$ of elderly GHD patients (aged 61-85 years) had a serum IGF1 lower than age-matched controls (22). Therefore, in a young patient IGF1 SDS may be helpful in indicating the presence of GHD, whereas in middle-aged or older patients it is less useful unless unequivocally low in the absence of intercurrent illness and hepatic dysfunction (23-25).

Aging is associated with LBM changes similar to those of GHD. Additionally, older hypopituitary patients often have apparently normal serum IGF1 levels (Fig. 1). It has therefore been questioned whether GHD is a distinct entity in the elderly hypopituitary patient or if the normal physiological decline in GH secretion with 


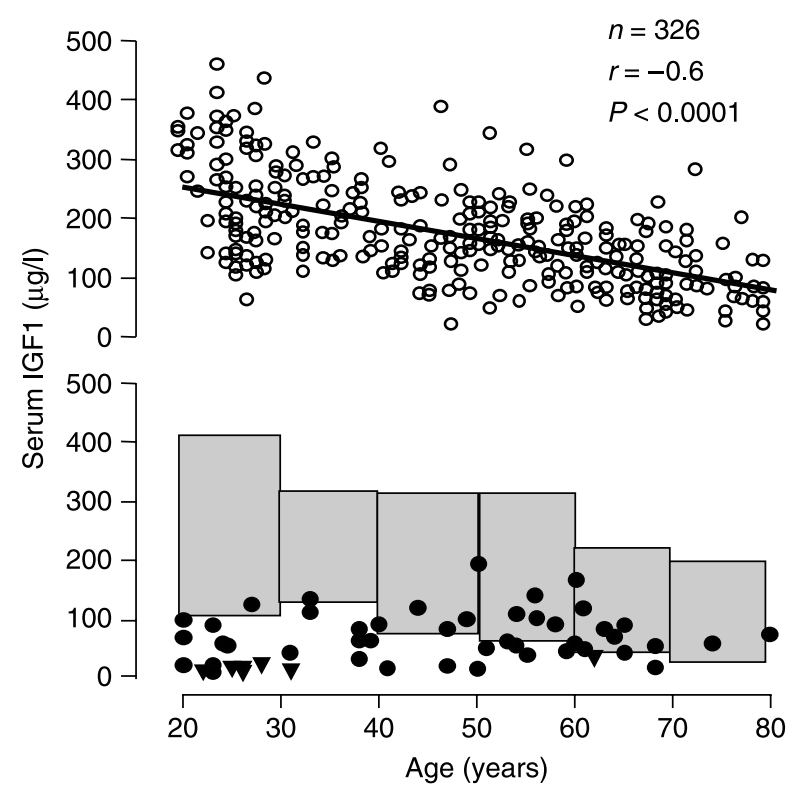

Figure 1 Age distribution of serum IGF1 levels in 326 healthy adults (20-80 years old) of both sexes (upper panel) and in 54 hypopituitary patient aged $20-80$ years (lower panel). Solid triangles are IGF1 levels in idiopathic GH deficiency. The shaded area depicts the $95 \%$ confidence levels in normal subjects per decade of life. (Ghigo E. European Journal of Endocrinology 1996 134 352-356. Reproduced with kind permission of the European Society of Endocrinology) (25).

age makes GHD a redundant diagnosis. However, there is good evidence that GHD not only causes symptoms in the elderly, but also that these individuals benefit from GH replacement. Elderly hypopituitary patients have an impaired GH response to provocation testing (22) and have increased fat mass (26) when compared with agematched controls. Furthermore, older patients respond to GH replacement with equal improvements in QoL and lipid profile when compared with younger patients (27) and demonstrate a possible improvement in mortality rate (28), thus confirming the value of replacing $\mathrm{GH}$ in this group.

\section{Clinical characteristics of the hypopituitary, GH deficient patient}

\section{Body composition}

GH and IGF1 influence, and are influenced by, body composition, with lean healthy individuals demonstrating higher GH but lower IGF1 levels than those who are obese. In GHD there is a reduction in LBM and an increase in fat mass, with central distribution. This may contribute towards some of the deleterious metabolic consequences of GHD (29). Even subtle changes in the GH-IGF1 axis may influence body composition: partial GHD (peak GH 5-11.8 $\mu \mathrm{g} / \mathrm{l}$ ) results in disadvantageous body changes in adolescents (12). Furthermore, other hormonal factors may contribute to the hypopituitary phenotype. Thus, GHD may mask central hypothyroidism (30) and may alter the cortisol/cortisone conversion set point, resulting in increased local tissue exposure to the effect of glucocorticoids (31).

GHD is consistently associated with body composition changes, irrespective of the aetiology of the GHD. However, GHD due to craniopharyngioma is associated with higher baseline rates of obesity than non-functioning pituitary adenoma (BMI 30.0 \pm 6.0 vs $\left.28.9 \pm 5.8 \mathrm{~kg} / \mathrm{m}^{2}, P<0.003\right)$ and an increase in weight after 2 years GH replacement (males $+2.5 \mathrm{~kg}$, $P<0.01$; females $+3.36 \mathrm{~kg}, P<0.0001)$ (32). These findings are presumed to be a consequence of hyperphagia resulting from hypothalamic damage by the tumour and/or its treatment. Patients who have received pituitary radiotherapy have been reported as having higher mean body fat mass than patients with non-irradiated tumours, a difference attenuated with 1 year of GH replacement (33). It has been suggested that this may be related to a direct effect of radiotherapy on the brain. However, it should be noted that in this study the radiotherapy patients had a longer period of GHD prior to replacement (11.5 vs 4.7 years) and that those treated with radiotherapy have a tendency towards most severe disease. GHD secondary to Cushing's disease and acromegaly is not associated with baseline differences in body composition when compared with other causes of GHD (34).

The deleterious effects of GHD on body composition are evident in both obese and non-obese patients and are reversed with GH replacement (35). Importantly, the inverse relationship between various measures of adiposity and indices of insulin sensitivity remains evident in normal weight hypopituitary patients (35), confirming that the adverse consequences of GHD on insulin action are related to specific changes in fat distribution and not simply to increased BMI.

The effects of GHD continue into later life, although in the elderly GHD is a less important cause of centripetal weight gain than in the younger patient. When middleaged and elderly GHD patients enrolled in the KIMS database were compared (mean age 47.9 vs 69.1 years), there was no difference in mean baseline BMI and waistto-hip ratio (WHR) in men (Table 1), but BMI and WHR were higher in older women than younger women (BMI 29.9 vs $28.2 \mathrm{~kg} / \mathrm{m}^{2}, P<0.02$; WHR 0.90 vs 0.86 , $P<0.01$; Table 2) (36). In this analysis, both men and women in each age category demonstrated an improvement in WHR with 1 year GH replacement (36). An analysis of different aged patients enrolled in HypoCCS confirmed this finding, with older GHD patients ( $>60$ years old) having a more pronounced decrease in WHR after 3 years GH treatment than younger patients, despite having no significant improvement in LBM (37). 
Table 1 Baseline characteristics of male patients aged over and under 65 years enrolled in the Pfizer International Metabolic Database (KIMS). Data are shown as mean \pm s.D. (Monson JP. Hormone Research 200360 112-120. Reproduced with kind permission of S Karger AG, Basel) (36).

\begin{tabular}{lccc}
\hline & Age $>\mathbf{6 5}$ years & Age $<\mathbf{6 5}$ years & $\boldsymbol{P}$ \\
\hline BMI $\left(\mathrm{kg} / \mathrm{m}^{2}\right)$ & $28.1 \pm 4.2$ & $28.9 \pm 4.9$ & 0.18 \\
Waist-to-hip ratio & $0.97 \pm 0.06$ & $0.97 \pm 0.09$ & 0.35 \\
Total cholesterol $(\mathrm{mM})$ & $5.79 \pm 1.07$ & $5.94 \pm 1.25$ & 0.71 \\
LDL-cholesterol $(\mathrm{mM})$ & $3.76 \pm 0.93$ & $3.85 \pm 1.17$ & 0.95 \\
HDL-cholesterol $(\mathrm{mM})$ & $1.20 \pm 0.36$ & $1.15 \pm 0.33$ & 0.28 \\
Triglycerides $(\mathrm{mM})$ & $1.90 \pm 0.92$ & $129.6 \pm 1.41$ & $<.17$ \\
Systolic BP $(\mathrm{mmHg})$ & $141.3 \pm 18.9$ & $80.9 \pm 11.2$ & $<0.0001$ \\
Diastolic BP (mmHg) & $83.3 \pm 10.4$ & $5.07 \pm 0.85$ & $<0.02$ \\
HbA1c (\%) & $5.34 \pm 0.76$ & 16.6 & $<.003$ \\
Prevalence of hypertension (\%) & 24.0 & 4.2 & 0.063 \\
Prevalence of diabetes mellitus (\%) & 3.9 & $9.0 \pm 6.6$ & 0.86 \\
QoL-AGHDA score & $7.9 \pm 6.4$ & 0.19 \\
\hline
\end{tabular}

HDL, high-density lipoprotein; LDL, low-density lipoprotein.

\section{Lipids}

The excess mortality in hypopituitary patients may be attributed, in part, to the adverse lipid profile associated with GHD. In an analysis of 2589 KIMS patients, $40 \%$ of GHD patients aged $<20$ years had total serum cholesterol (TC) above $5.3 \mathrm{mmol} / \mathrm{l}$. Mean TC increased linearly across age groups until it plateaued at 49 years so that in those aged 40 years, $75 \%$ of patients had a TC above $5.3 \mathrm{mmol} / \mathrm{l}$. Similar findings were seen in LDL-cholesterol (LDL-C), and to a lesser extent in triglycerides, with reciprocal changes in HDL-cholesterol (HDL-C). GH replacement was associated with significant improvements in TC, LDL-C and HDL-C but no change in triglycerides (38). Similar findings have been found in other studies $(29,39)$. Older patients also demonstrate lipid benefits with $\mathrm{GH}$ replacement. Monson et al. compared KIMS data for those aged over 65 years with younger patients and found no difference in baseline TC or LDL-C in men (Table 1), although differences were found in women (Table 2). Both younger and older groups had similar improvements in these parameters with $\mathrm{GH}$ replacement (36) (Fig. 2). Attanasio et al. reviewed results from 242 HypoCCS patients and reported the greatest improvement in $\mathrm{LDL} / \mathrm{HDL}$ ratio in patients aged 40-60 years when compared with both younger and older patients (37).

The advent of the HMG CoA-reductase inhibitors (statins) has provided powerful therapeutic tools for lowering serum TC and LDL-C, and reducing cardiovascular risk across the whole adult age range. The lipoprotein abnormalities evident in severe GHD (predominantly increased TC and LDL-C) may be significantly improved with statin therapy. To address the question as to whether additional benefit can be gained through GH replacement over and above that achieved with statin therapy, a prospective follow-up of 61 KIMS patients established on statins was performed. GH replacement achieved significant additional improvements in TC $(5.3 \pm 1.53 \mathrm{mmol} / \mathrm{l}$ at baseline; $4.9 \pm 1.08 \mathrm{mmol} / \mathrm{l}$ at 1 year) and LDL-C (3.1 $\pm 1.39 \mathrm{mmol} / \mathrm{l}$ at baseline; $2.6 \pm 0.81 \mathrm{mmol} / \mathrm{l}$ at 1 year; figures given are for females, male results were similar) (40), suggesting that both therapies may well be necessary in the GHD patient with a poor lipid profile.

Table 2 Baseline characteristics of female patients aged over and under 65 years enrolled in the Pfizer International Metabolic Database (KIMS). Data are shown as mean \pm s.D. (Monson JP. Hormone Research 200360 112-120. Reproduced with kind permission of S Karger AG, Basel) (36).

\begin{tabular}{|c|c|c|c|}
\hline & Age $>65$ years & Age $<65$ years & $\boldsymbol{P}$ \\
\hline $\mathrm{BMI}\left(\mathrm{kg} / \mathrm{m}^{2}\right)$ & $29.9 \pm 5.5$ & $28.2 \pm 6.0$ & $<0.02$ \\
\hline Waist-to-hip ratio & $0.90 \pm 0.07$ & $0.86 \pm 0.07$ & $<0.01$ \\
\hline Total cholesterol (mM) & $6.7 \pm 1.52$ & $6.12 \pm 1.27$ & $<0.01$ \\
\hline LDL-cholesterol (mM) & $4.42 \pm 1.41$ & $3.85 \pm 1.08$ & $<0.02$ \\
\hline HDL-cholesterol (mM) & $1.24 \pm 0.33$ & $1.39 \pm 0.38$ & $<0.02$ \\
\hline Triglycerides (mM) & $2.27 \pm 1.09$ & $2.05 \pm 1.96$ & $<0.02$ \\
\hline Systolic BP (mmHg) & $142.4 \pm 20.7$ & $125.7 \pm 17.9$ & $<0.02$ \\
\hline Diastolic BP $(\mathrm{mmHg})$ & $81.0 \pm 9.7$ & $79.4 \pm 10.5$ & 0.18 \\
\hline $\mathrm{HbA1c}(\%)$ & $5.58 \pm 0.99$ & $5.12 \pm 0.90$ & $<0.002$ \\
\hline Prevalence of hypertension (\%) & 43.1 & 13.6 & $<0.0001$ \\
\hline Prevalence of diabetes mellitus (\%) & 12.3 & 3.8 & $<0.002$ \\
\hline QoL-AGHDA score & $10.9 \pm 6.1$ & $11.5 \pm 6.8$ & 0.47 \\
\hline
\end{tabular}

HDL, high-density lipoprotein; LDL, low-density lipoprotein. 


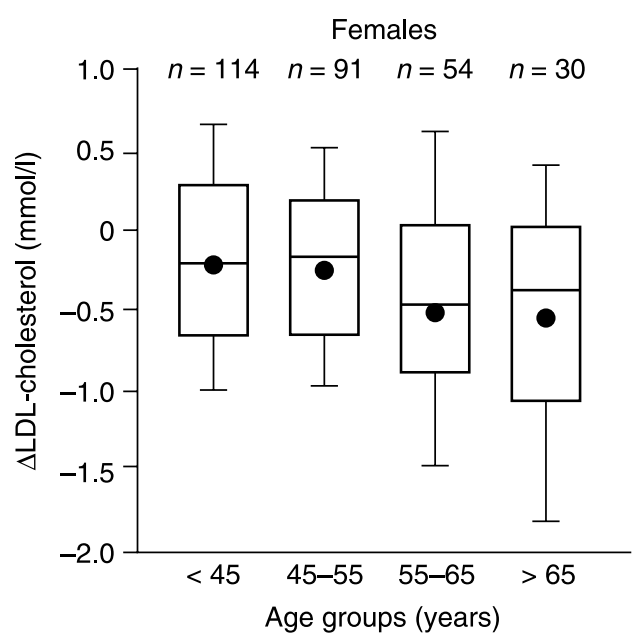

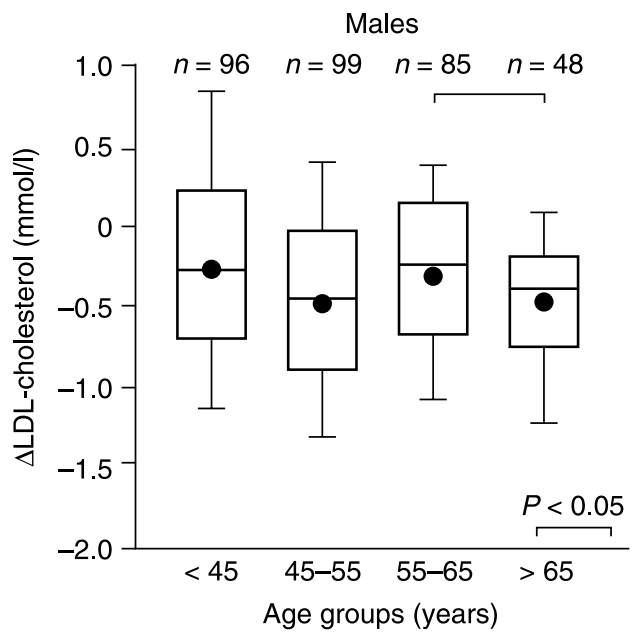

Figure 2 Changes in LDL-cholesterol in patients of different age groups after 1 year of GH replacement therapy. Data are shown as mean, median and $10-90$ th percentiles. $P<0.002$ for all groups verus baseline. (Monson JP. Hormone Research 2003 60 112-120. Reproduced with kind permission of S Karger AG, Basel) (36)

\section{Other cardiovascular risk factors}

A wealth of literature attests to the impact of GHD on cardiovascular risk. Both biochemical markers of increased atherogenesis, such as C-reactive protein (41), interleukin-6 (41) and homocysteine (42), and morphological markers, such as intima media thickness (43), have been shown to improve with GH replacement. GHD is associated with reduced cardiac output and a loss of cardiac response to exercise (44). Studies of cardiac morphology in GHD have shown variable outcomes in adult-onset disease (45-47) but consistently reduced cardiac muscle mass in childhoodonset GHD (48, 49). Furthermore, hypopituitarism is associated with increased cardiovascular mortality (3, 50) and GHD may be aetiologically implicated. The cardiovascular impact of long-standing GHD is such that reduction in cardiovascular risk has been cited as one of the aims of $\mathrm{GH}$ replacement in adolescence (11).

GH replacement is usually associated with a neutral effect on blood pressure (BP) (38); the antinatriuretic and possible chronotropic actions of $\mathrm{GH}$ are offset by vasodilation arising from increased generation of endothelial nitrous oxide. In studies where changes have been reported, these tend to reflect improvements in diastolic BP $(27,36,39,51)$. These findings may be less apparent in older patients. In a review of KIMS data, diastolic BP improved in both men and women $<65$ years and men $>65$ years (27). Improvement in systolic $\mathrm{BP}$ was seen in men $<65$ years and a trend to that effect was seen in men $>65$ years (27). No BP changes were seen in women $>65$ years $(27)$.

Hypopituitary patients have an increased prevalence of diabetes mellitus. In a review of 275 GH-naive KIMS patients, the prevalence of diabetes was significantly greater in women at $5.9 \%$ compared with control data from two European epidemiological studies (control prevalence $1.8-1.9 \%, P<0.05)$; a trend to increased prevalence in males was also present but was not statistically significant (52). These hypopituitary women were more obese than controls $(39.3 \%$ had a BMI $>30 \mathrm{~kg} / \mathrm{m}^{2}$ compared with $10.1 \%$ of controls), which is likely to have contributed towards this finding. Initially, there was concern that GH replacement would increase this prevalence further by increasing insulin resistance and hence diabetes rates. Although in the short term fasting plasma glucose may rise on commencing GH replacement (53), improvements in LBM and WHR offset these changes and in the longterm there is no rise in $\operatorname{HbAlc}(51,52)$ or plasma glucose (54). After 1 year of GH replacement, normalisation of insulin sensitivity and plasma glucose diurnal variation are seen (55). Normal aging is associated with an increased prevalence of diabetes across the whole population and this finding is also evident in GH-replaced GHD patients.

\section{Bone}

It is now accepted that GH replacement should not be discontinued in the GHD adolescent at the completion of linear growth but should be maintained until full somatic development has been achieved (11). These recommendations are based on studies by Drake et al. that showed that cessation of GH replacement in adolescents at the completion of linear growth is associated with negligible further gain in median total body bone mineral content (BMC) over 1 year $(+2.4 \%, P=0.5)$, whereas adolescents who continue to receive $\mathrm{GH}$ replacement continue to increase their median BMC $(+6.0 \%, P<0.001)$ (56). Shalet et al. confirmed these findings with a 2-year, multi-centre, randomised, non-blinded study comparing an adult $\mathrm{GH}$ replacement dose $(12.5 \mu \mathrm{g} / \mathrm{kg}$ per day $)$ to a paediatric 
GH replacement dose ( $25 \mu \mathrm{g} / \mathrm{kg}$ per day) and to no $\mathrm{GH}$ replacement in adolescents who had achieved final height; in addition to confirming the adverse effect of non-treatment with $\mathrm{GH}$, this study demonstrated no additional benefit in BMC from the higher GH dose (57). Interestingly, lumbar spine was the area that accrued the most additional BMC with GH therapy, an area particularly at risk from osteoporotic fractures.

Adult-onset GHD is associated with reduced bone mineral density (BMD) and increased likelihood of fractures. In a comparison of untreated GHD patients with controls from the European Vertebral Osteoporosis Study (EVOS), fracture prevalence in those aged $>60$ years was 2.66 times higher in the GHD population, with the most marked difference being in radial fracture rate; changes were significant $(P<0.05)$ in men but not in women $(P=0.06)$, which may relate to imperfect population matching and to the fact that the majority of women in this age group were not receiving oestrogen replacement, which might obscure the adverse consequences of GHD (58). Increased fracture rate was not associated with number of pituitary hormone deficiencies, suggesting adequacy of thyroxine and glucocorticoid replacement, BMI or country of origin, but was associated with smoking (58). In younger patients, similar changes were found. Interestingly, adult-onset GHD was associated with a higher fracture rate than childhood-onset GHD, although femoral neck and spinal Z-scores were similar (58). This may relate to the fact that those with childhood-onset GHD were younger and their background fracture risk lower.

Severe childhood and adult-onset GHD have been consistently associated with low BMD and BMC, which improve with GH replacement $(29,51,59)$. However, mild childhood-onset GHD (peak GH 3-11.8 $\mu \mathrm{g} / \mathrm{l}$ on provocation testing) appears to be associated with normal BMD (12) and improvements in BMC have been seen with what could be considered sub-therapeutic IGF1 levels (57). These observations suggest that modest improvements in GH status may be adequate to improve bone outcomes in younger patients. Gender may play a role in determining the response of BMD to GH replacement in adult-onset GHD. In a study of 13 patients receiving $\mathrm{GH}$ replacement, monitored over a median of 58 months (range 44-72), Drake et al. found a significant improvement in BMD in men whereas women demonstrated stabilisation only (60). This was despite an earlier increase in serum bone-specific alkaline phosphatase (a marker of bone formation) in women than the men (60). External pituitary radiotherapy may impact on bone health, as noted in a KIMS database analysis in which pituitary irradiation was associated with reduced BMC prior to GH replacement (mean BMC 2.4 vs $2.8 \mathrm{~kg}, P<0.01$ ) despite no difference in IGF1 SDS. This difference was attenuated by 2 years GH replacement and is, of course, subject to bias by virtue of differences in disease severity between the irradiated and non-irradiated patients (33).

In older patients, Toogood et al. found no difference in BMD in 21 patients (15 male) with hypothalamicpituitary disease aged over 60 years when compared with aged-matched controls (61). However, patients did have lower levels of biochemical markers of bone turnover, possibly explaining the increased fracture rate in this age group.

\section{Quality of life}

Hypopituitarism and GHD are associated with a reduction in psychological well-being as evidenced by patient reporting, generic QoL questionnaires, such as the Psychological General Well-Being Schedule and the
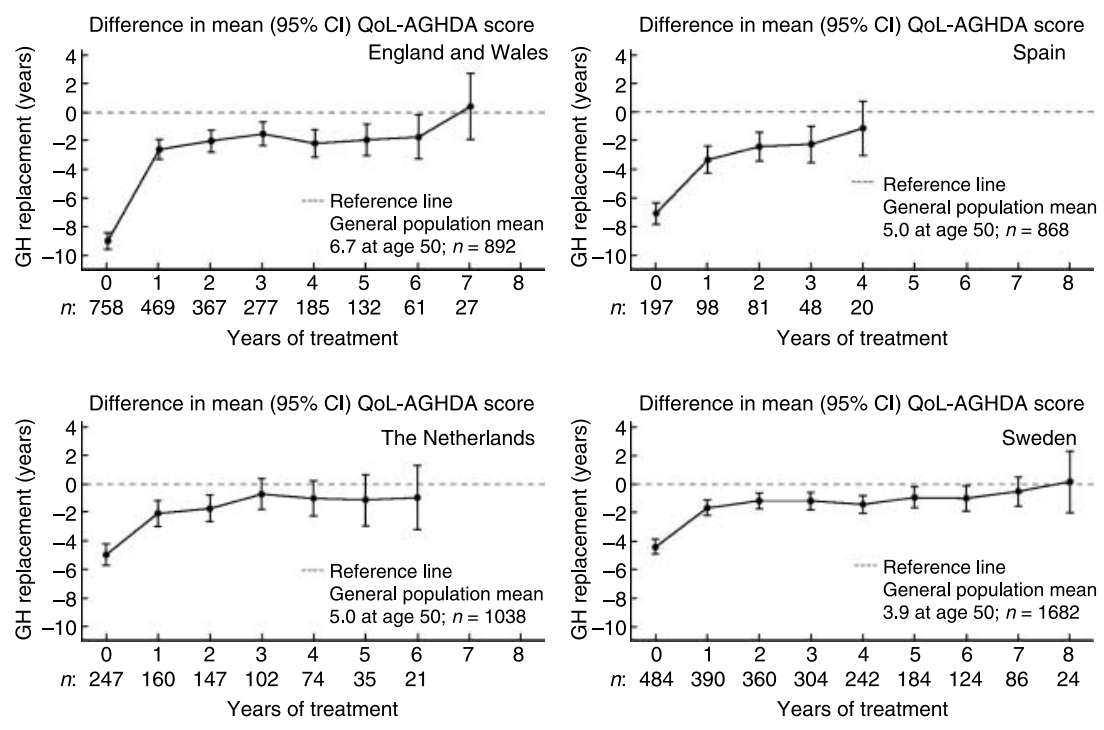

Figure 3 Country-specific differences in QoL-AGHDA total scores between general population and KIMS patients during GH replacement. $\mathrm{Cl}$, confidence interval, $n$, number of patients' data analysed at each timepoint. (Koltowska-Haggstrom M.

European Journal of Endocrinology 2006155 111. Reproduced with kind permission of the European Society of Endocrinology) (64). 
Nottingham Health Profile, and disease sensitive questionnaires, such as QoL-assessment of GHD in adults (AGHDA) (62) and questions on life satisfactionhypopituitarism (QLS-H) (63). Analysis of the different components of QoL-AGHDA scores demonstrates a consistent pattern of deficit with memory, concentration and tiredness affected earliest and problems with socialising affected only in more severe GHD. With treatment, these improve in reverse order (64). Some of the QoL improvements seen with GH replacement may arise from improvements in physical factors, such as increased circulating volume, exercise tolerance and muscle strength. Aetiology-specific differences in QoL are seen: craniopharyngioma (65), female gender (6, 39, 59), Sheehan's syndrome (66) and cranial irradiation (33) are all associated with worse baseline QoL, although it should be noted that all of these, with the exception of irradiation, are associated with particularly low IGF1 levels. Patients with isolated GHD reported in the KIMS database showed no difference in QoL between childhood and adult-onset disease using QoL-AGHDA questionnaires (59). However, patients in the HypoCCS database, assessed using QLS-H questionnaires, showed significantly worse QoL scores in adult-onset GHD (63). This may result from the use of Z-scores in QLS-H, unmasking differences in diseaseaffected individuals when compared with their peers, or may reflect the mixture of GHD aetiologies in the HypoCCS analysis, with other pathologies influencing QoL in addition to GHD. In this analysis, the authors describe a U-shaped curve of QoL in GHD, with those aged 35-45 years having lower baseline Z-scores when compared with those older or younger (63). This may reflect a true difference in QoL at different ages or may be confounded by personal expectations, as QLS-H is weighted according to how important each symptom is to the individual and these expectations may vary with age. The use of Z-scores removes the influence of the normal fall in QoL scores that may occur with aging.

In an analysis of 1686 patients with GHD enrolled into the KIMS database, QoL improved dramatically towards the country-specific population mean and approached normality by 1 year, with changes sustained at 5 years (64) (Fig. 3). Poor baseline QoLAGHDA score predicts a greater psychosocial response to $\mathrm{GH}$ replacement (65). There seems to be no difference in improvement in QoL in adult patients of different ages, with older patients deriving as much benefit from $\mathrm{GH}$ replacement as those who are younger $(27,36,39)$ (Fig. 4).

\section{Optimising GH treatment}

Initial GH replacement doses were based on body weight or surface area. This resulted in side effects including fluid retention, carpel tunnel syndrome and arthralgia in a substantial proportion of patients. Current practice
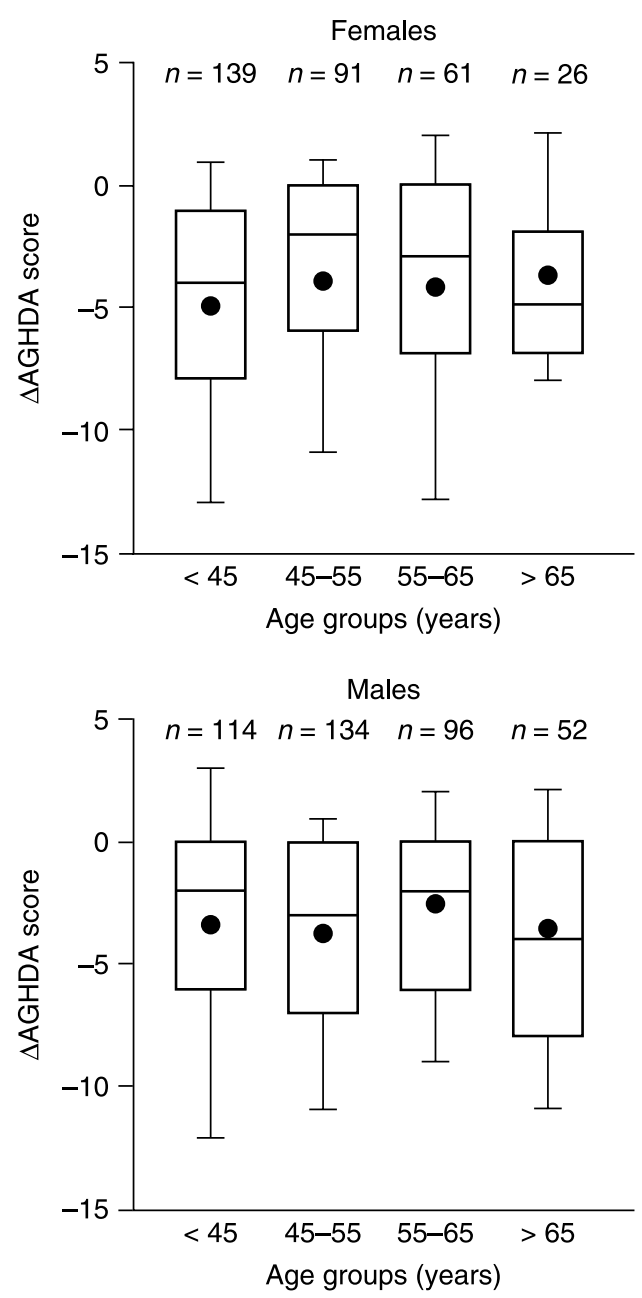

Figure 4 Change in QoL-AGHDA scores in patients of different age groups after 1 year of GH replacement therapy. Data are shown as mean, median and 10-90th percentiles. (Monson JP. Hormone Research 200360 112-120. Reproduced with kind permission of S Karger AG, Basel) (36).

has eliminated this problem by the initiation of low doses, with titration against serum IGF1 and clinical improvement to determine final dose, resulting in excellent tolerability (10). Although an insensitive marker of the presence of disease, especially in the elderly, IGF1 provides a useful guide to the physician for dose adjustment and is an essential safety marker to avoid over-treatment. The established practice of aiming for a serum IGF1 in the upper half of the age-adjusted reference range is supported by the work of Drake et al. (67) and Mukherjee et al. (68). This approach results in higher $\mathrm{GH}$ doses in women $(39,67)$ as would be predicted from normal physiology in which similar IGF1 levels are dependent on higher $\mathrm{GH}$ secretion in females. The mechanism of this gender difference is incompletely understood, although oestrogen-mediated changes in IGF1 generation are a significant contributor. 
As healthy individuals age, circulating IGF1 levels fall. Therefore, aiming for an IGF1 level in the upper half of the age-adjusted reference range results in lower GH doses being given to older patients.

\section{Conclusion}

Both childhood and adult-onset GHD result in a broad range of physical and psychological side effects in adult life. At each phase of adult life, different individual aspects may predominate in determining the need for GH replacement. However, most consequences of GHD have impact throughout adult life, and demonstrate benefit from GH replacement. The importance of diagnosing and treating GHD in the elderly should not be underestimated as older hypopituitary patients demonstrate significant improvement in QoL and physical well-being with GH therapy. When diagnosing GHD and monitoring GH replacement, appropriate testing should be used to ensure the correct diagnosis and safe management and age-related reference ranges for IGF1 are employed. KIMS and other similar databases have provided an invaluable contribution to our understanding of GH replacement and its safety.

\section{Declaration of interest}

The authors declare that there is no conflict of interest that could be perceived as prejudicing the impartiality of the research reported. KIMS $^{\circledR}$ is supported by Pfizer Inc. This paper forms part of a European Journal of Endocrinology supplement, supported by Pfizer Inc.

\section{References}

1 Ranke MB \& Dowie J. KIGS and KIMS as tools for evidence-based medicine. Hormone Research 199951 83-86.

2 Gutierrez LP, Koltowska-Häggström M, Jonsson PJ, Mattsson AF, Svensson D, Westberg B \& Luger A. Registries as a tool in evidencebased medicine: example of KIMS (Pfizer International Metabolic Database). Pharmacoepidemiology and Drug Safety $2008 \mathbf{1 7}$ 90-102.

3 Rosen T \& Bengtsson BA. Premature mortality due to cardiovascular disease in hypopituitarism. Lancet 1990336 285-288.

4 Tomlinson JW, Holden N, Hills RK, Wheatley K, Clayton RN, Bates AS, Sheppard MC \& Stewart PM. Association between premature mortality and hypopituitarism. West Midlands Prospective Hypopituitary Study Group. Lancet 2001357 425-431.

5 Bates AS, Van't Hoff W, Jones PJ \& Clayton RN. The effect of hypopituitarism on life expectancy. Journal of Clinical Endocrinology and Metabolism 199681 1169-1172.

6 Svensson J, Mattsson A, Rosen T, Wiren L, Johannsson G, Bengtsson BA \& Koltowska Häggström M. Three-years of growth hormone $(\mathrm{GH})$ replacement therapy in GH-deficient adults: effects on quality of life, patient-reported outcomes and healthcare consumption. Growth Hormone and IGF Research $2004 \mathbf{1 4}$ 207-215.

7 Hoffman DM, O'Sullivan AJ, Baxter RC \& Ho KK. Diagnosis of growth-hormone deficiency in adults. Lancet $1994 \mathbf{3 4 3}$ 1064-1068.
8 Jones SL, Trainer PJ, Perry L, Wass JA, Bessser GM \& Grossman A. An audit of the insulin tolerance test in adult subjects in an acute investigation unit over one year. Clinical Endocrinology 199441 123-128.

9 Kopelman PG, White N, Pilkington TR \& Jeffcoate SL. Impaired hypothalamic control of prolactin secretion in massive obesity. Lancet $19791747-750$.

10 Consensus guidelines for the diagnosis and treatment of adults with growth hormone deficiency: summary statement of the growth hormone research society workshop on adult growth hormone deficiency. Journal of Clinical Endocrinology and Metabolism 199883 379-381.

11 Clayton PE, Cuneo RC, Juul A, Monson JP, Shalet SM \& Tauber M. Consensus statement on the management of the GH-treated adolescent in the transition to adult care. European Journal of Endocrinology 2005152 165-170.

12 Tauber M, Jouret B, Cartault A, Lounis N, Gayrard M, Marcouyeux C, Pienkowski C, Oliver I, Moulin P, Otal P, Joffre F, Arnaud C \& Rochiccioli P. Adolescents with partial growth hormone (GH) deficiency develop alterations of body composition after GH discontinuation and require follow-up. Journal of Clinical Endocrinology and Metabolism 200388 5101-5106.

13 Kalk WJ, Vinik AI, Pimstone BL \& Jackson PU. Growth hormone response to insulin hypoglycemia in the elderly. Journal of Gerontology 197328 431-433.

14 Muggeo M, Fedele D, Tiengo A, Molinari M \& Crepaldi G. Human growth hormone and cortisol response to insulin stimulation in aging. Journal of Gerontology $197530546-551$.

15 Ho KK. Consensus guidelines for the diagnosis and treatment of adults with GH deficiency II: a statement of the GH Research Society in association with the European Society for Pediatric Endocrinology. Lawson Wilkins Society, European Society of Endocrinology, Japan Endocrine Society, and Endocrine Society of Australia. European Journal of Endocrinology $2007 \mathbf{1 5 7}$ 695-700.

16 Cain JP, Williams GH \& Dluhy RG. Glucagon-initiated human growth hormone release: a comparative study. Canadian Medical Association Journal 1972107 617-622.

17 Rahim A, Toogood AA \& Shalet SM. The assessment of growth hormone status in normal young adult males using a variety of provocative agents. Clinical Endocrinology 199645 557-562.

18 Molitch ME, Clemmons DR, Malozowski S, Merriam GR, Shalet SM, Vance ML \& Stephens PA. Evaluation and treatment of adult growth hormone deficiency: an Endocrine Society Clinical Practice Guideline. Journal of Clinical Endocrinology and Metabolism 200691 1621-1634.

19 Micic D, Popovic V, Kendereski A, Macut D, Casanueva FF \& Dieguez C. Growth hormone secretion after the administration of GHRP-6 or GHRH combined with GHRP-6 does not decline in late adulthood. Clinical Endocrinology 199542 191-194.

20 Webb SM, Strasburger CJ, Mo D, Hartman ML, Melmed S, Jung H, Blum WF \& Attanasio AF. Changing patterns of the adult growth hormone deficiency diagnosis documented in a decade-long global surveillance database. Journal of Clinical Endocrinology and Metabolism 200994 392-399.

21 de Boer H, Blok GJ, Popp-Snijders C \& van der Veen EA. Diagnosis of growth hormone deficiency in adults. Lancet $1994 \mathbf{3 4 3}$ $1645-1646$.

22 Toogood AA, O'Neill PA \& Shalet SM. Beyond the somatopause: growth hormone deficiency in adults over the age of 60 years. Journal of Clinical Endocrinology and Metabolism $1996 \mathbf{8 1}$ $460-465$.

23 Shalet SM, Toogood A, Rahim A \& Brennan BM. The diagnosis of growth hormone deficiency in children and adults. Endocrine Reviews 199819 203-223.

24 Harris T, Roubenoff R, Kiel D, Langlois J, Havlik R \& Wilson P. Diagnosis of growth hormone deficiency in adults. Lancet 1994 3431646.

25 Ghigo E, Aimaretti G, Gianotti L, Bellone J, Arvat E \& Camanni F. New approach to the diagnosis of growth hormone deficiency in adults. European Journal of Endocrinology 1996134 352-356. 
26 Toogood AA, Adams JE, O’Neill PA \& Shalet SM. Body composition in growth hormone deficient adults over the age of 60 years. Clinical Endocrinology 199645 399-405.

27 Monson JP, Abs R, Bengtsson BA, Bennmarker H, FeldtRasmussen U, Hernberg-Stahl E, Thoren M, Westberg B, Wilton P \& Wuster C. Growth hormone deficiency and replacement in elderly hypopituitary adults. KIMS Study Group and the KIMS International Board. Pharmacia and Upjohn International Metabolic Database. Clinical Endocrinology 2000 53 281-289.

28 Mattsson A. Total and cause-specific mortality in patients from the KIMS database: direct evidence for a beneficial effect of $\mathrm{GH}$ replacement therapy on mortality in adult GH deficient patients. Presented at European Congress of Endocrinology 2008, Berlin, Germany. Endocrine Abstracts 200816 P404.

29 Carroll PV, Christ ER, Bengtsson BA, Carlsson L, Christiansen JS, Clemmons D, Hintz R, Ho K, Laron Z, Sizonenko P, Sonksen PH, Tanaka T \& Thorne M. Growth hormone deficiency in adulthood and the effects of growth hormone replacement: a review. Growth Hormone Research Society Scientific Committee. Journal of Clinical Endocrinology and Metabolism 199883 382-395.

30 Agha A, Walker D, Perry L, Drake WM, Chew SL, Jenkins PJ, Grossman AB \& Monson JP. Unmasking of central hypothyroidism following growth hormone replacement in adult hypopituitary patients. Clinical Endocrinology 200766 72-77.

31 Gelding SV, Taylor NF, Wood PJ, Noonan K, Weaver JU, Wood DF \& Monson JP. The effect of growth hormone replacement therapy on cortisol-cortisone interconversion in hypopituitary adults: evidence for growth hormone modulation of extrarenal $11 \beta$-hydroxysteroid dehydrogenase activity. Clinical Endocrinology 199848 153-162.

32 Verhelst J, Kendall-Taylor P, Erfurth EM, Price DA, Geffner M, Koltowska-Häggström M, Jonsson PJ, Wilton P \& Abs R. Baseline characteristics and response to 2 years of growth hormone (GH) replacement of hypopituitary patients with GH deficiency due to adult-onset craniopharyngioma in comparison with patients with nonfunctioning pituitary adenoma: data from KIMS (Pfizer International Metabolic Database). Journal of Clinical Endocrinology and Metabolism 200590 4636-4643.

33 Maiter D, Abs R, Johannsson G, Scanlon M, Jonsson PJ, Wilton P \& Koltowska-Häggström M. Baseline characteristics and response to GH replacement of hypopituitary patients previously irradiated for pituitary adenoma or craniopharyngioma: data from the Pfizer International Metabolic Database. European Journal of Endocrinology 2006155 253-260.

34 Feldt-Rasmussen U, Abs R, Bengtsson BA, Bennmarker H, Bramnert M, Hernberg-Stahl E, Monson JP, Westberg B, Wilton P \& Wuster C. Growth hormone deficiency and replacement in hypopituitary patients previously treated for acromegaly or Cushing's disease. European Journal of Endocrinology $200214667-74$.

35 Weaver JU, Monson JP, Noonan K, John WG, Edwards A, Evans KA \& Cunningham J. The effect of low dose recombinant human growth hormone replacement on regional fat distribution, insulin sensitivity, and cardiovascular risk factors in hypopituitary adults. Journal of Clinical Endocrinology and Metabolism $1995 \mathbf{8 0}$ 153-159.

36 Monson JP \& Jonsson P. Aspects of growth hormone $(\mathrm{GH})$ replacement in elderly patients with $\mathrm{GH}$ deficiency: data from KIMS. Hormone Research $200360112-120$.

37 Attanasio AF, Bates PC, Ho KK, Webb SM, Ross RJ, Strasburger CJ, Bouillon R, Crowe B, Selander K, Valle D \& Lamberts SW. Human growth hormone replacement in adult hypopituitary patients: long-term effects on body composition and lipid status-3-year results from the HypoCCS Database. Iournal of Clinical Endocrinology and Metabolism 200287 1600-1606.

38 Abs R, Feldt-Rasmussen U, Mattsson AF, Monson JP, Bengtsson BA, Goth MI, Wilton P \& Koltowska-Häggström M. Determinants of cardiovascular risk in 2589 hypopituitary GH-deficient adults - a KIMS database analysis. European Journal of Endocrinology $2006 \mathbf{1 5 5}$ 79-90.
39 Bengtsson BA, Abs R, Bennmarker H, Monson JP, FeldtRasmussen U, Hernberg-Stahl E, Westberg B, Wilton P \& Wuster $\mathrm{C}$. The effects of treatment and the individual responsiveness to growth hormone (GH) replacement therapy in 665 GH-deficient adults. KIMS Study Group and the KIMS International Board. Journal of Clinical Endocrinology and Metabolism 199984 3929-3935.

40 Monson JP, Jonsson P, Koltowska-Häggström M \& Kourides I. Growth hormone $(\mathrm{GH})$ replacement decreases serum total and LDL-cholesterol in hypopituitary patients on maintenance HMG CoA reductase inhibitor (statin) therapy. Clinical Endocrinology 200767 623-628.

41 Sesmilo G, Biller BM, Llevadot J, Hayden D, Hanson G, Rifai N \& Klibanski A. Effects of growth hormone administration on inflammatory and other cardiovascular risk markers in men with growth hormone deficiency. A randomized, controlled clinical trial. Annals of Internal Medicine 2000133 111-122.

42 Sesmilo G, Biller BM, Llevadot J, Hayden D, Hanson G, Rifai N \& Klibanski A. Effects of growth hormone (GH) administration on homocyst(e)ine levels in men with GH deficiency: a randomized controlled trial. Journal of Clinical Endocrinology and Metabolism 200186 1518-1524.

43 Pfeifer M, Verhovec R, Zizek B, Prezelj J, Poredos P \& Clayton RN. Growth hormone $(\mathrm{GH})$ treatment reverses early atherosclerotic changes in GH-deficient adults. Journal of Clinical Endocrinology and Metabolism 199984 453-457.

44 Cittadini A, Cuocolo A, Merola B, Fazio S, Sabatini D, Nicolai E, Colao A, Longobardi S, Lombardi G \& Sacca L. Impaired cardiac performance in GH-deficient adults and its improvement after GH replacement. American Journal of Physiology $1994 \mathbf{2 6 7}$ E219-E225.

45 Colao A, di Somma C, Cuocolo A, Spinelli L, Tedesco N, Pivonello R, Bonaduce D, Salvatore M \& Lombardi G. Improved cardiovascular risk factors and cardiac performance after 12 months of growth hormone (GH) replacement in young adult patients with GH deficiency. Journal of Clinical Endocrinology and Metabolism 200186 1874-1881.

46 Climent VE, Pico A, Sogorb F, Aznar S, Lip GY \& Marin F. Growth hormone therapy and the heart. American Journal of Cardiology 200697 1097-1102.

47 Maison P \& Chanson P. Cardiac effects of growth hormone in adults with growth hormone deficiency: a meta-analysis. Circulation 2003108 2648-2652.

48 Amato G, Carella C, Fazio S, La Montagna G, Cittadini A, Sabatini D, Marciano-Mone C, Sacca L \& Bellastella A. Body composition, bone metabolism, and heart structure and function in growth hormone (GH)-deficient adults before and after GH replacement therapy at low doses. Journal of Clinical Endocrinology and Metabolism 199377 1671-1676.

49 Merola B, Cittadini A, Colao A, Longobardi S, Fazio S, Sabatini D, Sacca L \& Lombardi G. Cardiac structural and functional abnormalities in adult patients with growth hormone deficiency. Journal of Clinical Endocrinology and Metabolism $1993 \quad \mathbf{7 7}$ $1658-1661$.

50 Toogood A. Cardiovascular risk in patients with GHD. In Growth Hormone Deficiency in Adults: 10 Years of KIMS, pp 63-74. Eds R Abs \& U Feldt-Rasmussen 2004.

51 Fideleff HL, Boquete HR, Stalldecker G, Giaccio AV \& Sobrado PG. Comparative results of a 4-year study on cardiovascular parameters, lipid metabolism, body composition and bone mass between untreated and treated adult growth hormone deficient patients. Growth Hormone and IGF Research $2008 \mathbf{1 8}$ 318-324.

52 Abs R, Bengtsson BA, Hernberg-Stahl E, Monson JP, Tauber JP, Wilton P \& Wuster C. GH replacement in 1034 growth hormone deficient hypopituitary adults: demographic and clinical characteristics, dosing and safety. Clinical Endocrinology $1999 \quad \mathbf{5 0}$ 703-713.

53 Woodmansee WW, Hartman ML, Lamberts SW, Zagar AJ \& Clemmons DR. Occurrence of impaired fasting glucose in 
GH-deficient adults receiving $\mathrm{GH}$ replacement compared to untreated subjects. Clinical Endocrinology, 2009. In Press DOI: $10.1111 /$ j.1365-2265.2009.03612.x.

54 Monson JP, Bengtsson BA, Abs R, Feldt-Rasmussen U \& Wuster C. Can growth hormone therapy cause diabetes? KIMS Strategic Committee Lancet 2000355 1728-1729.

55 Hwu CM, Kwok CF, Lai TY, Shih KC, Lee TS, Hsiao LC, Lee SH, Fang VS \& Ho LT. Growth hormone (GH) replacement reduces total body fat and normalizes insulin sensitivity in GH-deficient adults: a report of one-year clinical experience. Journal of Clinical Endocrinology and Metabolism 199782 3285-3292.

56 Drake WM, Carroll PV, Maher KT, Metcalfe KA, CamachoHubner C, Shaw NJ, Dunger DB, Cheetham TD, Savage MO \& Monson JP. The effect of cessation of growth hormone $(\mathrm{GH})$ therapy on bone mineral accretion in GH-deficient adolescents at the completion of linear growth. Journal of Clinical Endocrinology and Metabolism $2003 \mathbf{8 8} 1658-1663$.

57 Shalet SM, Shavrikova E, Cromer M, Child CJ, Keller E, Zapletalova J, Moshang T, Blum WF, Chipman JJ, Quigley CA \& Attanasio AF. Effect of growth hormone $(\mathrm{GH})$ treatment on bone in postpubertal GH-deficient patients: a 2-year randomized, controlled, dose-ranging study. Journal of Clinical Endocrinology and Metabolism $2003 \mathbf{8 8} 4124-4129$.

58 Wuster $\mathrm{C}$, Abs R, Bengtsson BA, Bennmarker H, FeldtRasmussen U, Hernberg-Stahl E, Monson JP, Westberg B \& Wilton P. The influence of growth hormone deficiency, growth hormone replacement therapy, and other aspects of hypopituitarism on fracture rate and bone mineral density. Journal of Bone and Mineral Research 200116 398-405.

59 Abs R, Mattsson AF, Bengtsson BA, Feldt-Rasmussen U, Goth MI, Koltowska-Häggström M, Monson JP, Verhelst J \& Wilton P. Isolated growth hormone $(\mathrm{GH})$ deficiency in adult patients: baseline clinical characteristics and responses to $\mathrm{GH}$ replacement in comparison with hypopituitary patients. A sub-analysis of the KIMS database. Growth Hormone and IGF Research 200515 349-359.

60 Drake WM, Rodriguez-Arnao J, Weaver JU, James IT, Coyte D, Spector TD, Besser GM \& Monson JP. The influence of gender on the short and long-term effects of growth hormone replacement on bone metabolism and bone mineral density in hypopituitary adults: a 5-year study. Clinical Endocrinology 2001 54 525-532.
61 Toogood AA, Adams JE, O'Neill PA \& Shalet SM. Elderly patients with adult-onset growth hormone deficiency are not osteopenic. Journal of Clinical Endocrinology and Metabolism 199782 1462-1466.

62 Doward L. The development of the AGHDA score: a measure to assess quality of life of adults with growth hormone deficiency. Quality of Life Research 19954 20-21.

63 Rosilio M, Blum WF, Edwards DJ, Shavrikova EP, Valle D, Lamberts SW, Erfurth EM, Webb SM, Ross RJ, Chihara K, Henrich G, Herschbach P \& Attanasio AF. Long-term improvement of quality of life during growth hormone (GH) replacement therapy in adults with GH deficiency, as measured by questions on life satisfaction-hypopituitarism (QLS-H). Journal of Clinical Endocrinology and Metabolism 200489 1684-1693.

64 Koltowska-Häggström M, Mattsson AF, Monson JP, Kind P, Badia X, Casanueva FF, Busschbach J, Koppeschaar HP \& Johannsson G. Does long-term GH replacement therapy in hypopituitary adults with GH deficiency normalise quality of life? European Journal of Endocrinology 2006155 109-119.

65 Saller B, Mattsson AF, Kann PH, Koppeschaar HP, Svensson J, Pompen M \& Koltowska-Häggström M. Healthcare utilization, quality of life and patient-reported outcomes during two years of $\mathrm{GH}$ replacement therapy in GH-deficient adults - comparison between Sweden, The Netherlands and Germany. European Journal of Endocrinology 2006154 843-850.

66 Kelestimur F, Jonsson P, Molvalilar S, Gomez JM, Auernhammer CJ, Colak R, Koltowska-Häggström M \& Goth MI. Sheehan's syndrome: baseline characteristics and effect of 2 years of growth hormone replacement therapy in 91 patients in KIMS Pfizer International Metabolic Database. European Journal of Endocrinology 2005152 581-587.

67 Drake WM, Coyte D, Camacho-Hubner C, Jivanji NM, Kaltsas G, Wood DF, Trainer PJ, Grossman AB, Besser GM \& Monson JP. Optimizing growth hormone replacement therapy by dose titration in hypopituitary adults. Journal of Clinical Endocrinology and Metabolism $1998 \mathbf{8 3} 3913-3919$.

68 Mukherjee A, Monson JP, Jonsson PJ, Trainer PJ \& Shalet SM. Seeking the optimal target range for insulin-like growth factor I during the treatment of adult growth hormone disorders. Journal of Clinical Endocrinology and Metabolism $2003 \mathbf{8 8} 5865-5870$.

Received 11 June 2009

Accepted 16 June 2009 